\title{
Vocabulary Acquisition in English as a Foreign Language: Digital Gameplaying The Sims
}

\author{
Caroline Chioquetta Lorenset ${ }^{1}$ \\ Instituto Federal de Santa Catarina, Florianópolis, SC, Brasil \\ Celso Henrique Soufen Tumolo ${ }^{2}$ \\ Programa de Pós-Graduação em Inglês, Universidade Federal de Santa Catarina, Florianópolis, SC, Brasil
}

\begin{abstract}
The use of digital technological resources for educational settings is a quite recent phenomenon (SAVI; ULBRICHT, 2008). Although recent research emphasizes the importance of integrating technology into the curriculum, its use can only be effective for learning if well integrated in a meaningful way in the classroom (PRENSKY, 2007; SQUIRE, 2006). This article aims to characterize vocabulary acquisition and the use of the digital game The Sims, and to investigate if and how it can assist vocabulary of English as a foreign language. Data collected involved participants of a public school setting in Florianópolis, SC, Brazil. The instruments used were a pre-test, a post-test, a delayed post-test, as well as a narrative writing. Results indicated The Sims as effective for vocabulary acquisition in EFL, since it deals with routine and familiar vocabulary and offers a new virtual life and contextual learning for players.
\end{abstract}

Keywords: Digital Games; English as a Foreign Language; Technology for Teaching and Learning; The Sims.

Resumo: $O$ uso de recursos digitais para ambientes educacionais é um fenômeno bastante recente (SAVI; ULBRICHT, 2008). Embora pesquisas enfatizem a importância de integrar a tecnologia no currículo escolar, seu uso só se torna eficaz se bem integrado de forma significativa na sala de aula (PRENSKY, 2007; SQUIRE, 2006). Este artigo tem como objetivo caracterizar a aquisição de vocabulário e o uso do jogo digital The Sims, e investigar se e como auxilia no aprendizado de vocabulário de inglês como língua estrangeira. Os dados coletados envolveram participantes de uma escola pública em Florianópolis, SC, Brasil. Os instrumentos utilizados foram um pré-teste, um pós-teste, e um pós-teste postergado, bem como a escrita de uma narrativa. Os resultados indicaram The Sims como ferramenta eficaz para aquisição de vocabulário em inglês, uma vez que lida com vocabulário rotineiro e familiar e oferece uma nova vida virtual e aprendizado contextual para os jogadores.

Palavras-chave: Jogos Digitais; Inglês como uma língua estrangeira; Tecnologia para Ensino e Aprendizagem; The Sims.

\footnotetext{
${ }^{1}$ Doutora (UFSC), Instituto Federal de Santa Catarina. http://orcid.org/0000-0002-1999-0134

E-mail: caroline.lorenset@ifsc.edu.br

${ }^{2}$ Doutor (UFSC), Universidade Federal de Santa Catarina. http://orcid.org/0000-0001-5045-8712

E-mail: celso.tumolo@ufsc.br
} 


\section{Introduction}

Since their origin, in the 1950s, digital games have been conquering new spaces and new audiences in people's leisure time, either for their motivational aspect, their prompt feedback, or their interactional and multimodal appeal. In the last decades, digital games have become an art form and an industry (SAVI; ULBRICHT, 2008), winning over a special place in industry and media markets in our contemporary culture.

Digital games can be characterized by several aspects, such as virtual characters or avatars, narratives, rules, restrictions, interactions, challenges, competitions, objectives, rewards and feedback (PRENSKY, 2007; WANGENHEIM; WANGENHEIM, 2012) that may contribute to learning and development of cognitive processes of players. Therefore, digital games can be seen as attractive and interactive environments that capture players' attention offering challenges with an increasing level of skills.

In general, digital games can be defined as environments involving human interaction with virtual reality. This interaction among humans and digital technologies happens usually on video devices such as a television screens, game consoles or computer monitors, which are further known by gamers as platforms (JAVERLÄ; EKMA; KIVIKANGAS; RAVAJA, 2014). By selecting a platform to play, different game controllers can vary accordingly, although common controllers include mouse and keyboard for a television platform, for instance, a joystick and buttons to control the game via a game console, or touchscreen of mobile devices to play in gadgets, such as smartphones and tablets.

Numerous studies (e.g. CHIK, 2011; GEE, 2005; GEE; HAYES, 2010; SQUIRE, 2006; SYKES; REINHARDT, 2013; TUMOLO, 2014) address digital games as learning tools of several scholar areas and content subjects, including, among others, the learning of a foreign language. Moran (2013) mentioned that digital technologies for educational purposes are growing in number use and frequency, and they have been making changes not only at family homes but in the scholar system as well. Hence, abilities, experiences and previous knowledge of the players become important sources to be explored and included in pedagogic and didactic choices by teachers and educators. In this context, digital games can be mentioned as a learning innovative tool that may allow active and meaningful learning in context, and interaction among players, enhancing, thus, opportunities to experience and visualize concepts and new worlds, and to develop gamers' creativity and interest (DEMPSEY; LUCASSEN; HAYNES; CASEY, 1996; GRAMIGNA, 2007) in different subjects and areas.

Also, previous research (e.g. AGHLARA; TAMJID, 2011; EBRAHIMI; ZAMANIAN, 2013; RAMOS; LORENSET; PETRI, 2016; SAFFARIAN; GORJIAN, 2012; SAHRIR; ALIAS, 2011) have stated that digital games present potentialities by showing information in different modes, increasingly offering opportunities for vocabulary learning by being repetitive, providing instantaneous feedback, and offering players an environment where they can play and learn at their own pace. 
Besides being present in our daily lives, digital games can bring pleasure into learning (GEE, 2005, 2009; SQUIRE, 2006), either by relaxing and easing considerably players to take decisions and make mistakes, or by motivating players to model the virtual scenarios and avatars according to their interests - all of these in the foreign language. Gee (2005) stated that good digital games represent good learning, allowing learners to feel like active agents making choices, not just passive recipients receiving the work done. By being active agents, players can learn through different styles, in addition to learning new skills, strategies, and consolidating ideas and concepts, consolidating in practice how school subjects can fit in bigger contexts (GEE, 2005).

Overall, digital games have been growing as field of research in the area of learning foreign languages, especially because they conquer and motivate players. Researchers (e.g. GEE, 2005; SQUIRE, 2006; CHIK, 2011) have been investigating how digital games can function in classroom settings for learning purposes, and have established positive factors, aspects, characteristics and elements that may trigger learning.

By investigating a possible correlation among digital games and learning outcomes, several researchers (e.g. AGHLARA; TAMJID, 2011; EBRAHIMI; ZAMANIAN, 2013; GORJIAN, 2012; RAMOS; LORENSET; PETRI, 2016; SAFFARIAN; SAHRIR; ALIAS, 2011) have stated the benefits of digital gaming and how they can facilitate players learning performance. Some of the benefits mentioned by their investigations are factual knowledge, problem-solving strategies, and higher-level cognitive thinking processes, enhancing students' computer skills and digital literacy. Learning through digital games, furthermore, goes beyond language learning boundaries, and are beneficial for players social and cognitive skills.

When investigating general broader learning principles triggered by digital gaming, Gee (2005) proposed the following aspects that assist learning: 1) co-design; 2) customization; 3) identity; 4) manipulation and distributed knowledge; 5) well-ordered problems; 6) cycles of expertise; 7) information 'on demand' and 'just in time'; 8) skills and strategies development; 9) system thinking; among others. The author stated that these aspects are available on good digital games, and that they act deeply in cognitive processes because they prompt deep learning to a parcel of fun (GEE, 2005).

In a similar vein, Squire (2006) stated that a core characteristic of digital games is that they are organized around doing and being. By doing actions in context and by being someone else in virtual worlds, players become agent learners, which is a core characteristic of learning: through performance. As a result, many contemporary digital games literally put players inside the game, allowing them to create new identities and create a life setting in a new virtual environment. As a matter of example, Wii games allow players to become tennis players, dancers or drivers, acting like them for real: players are inserted in tennis matches where they have to move their tennis racquets faster than their opponents; they have to be dancers good enough to follow the songs' beats in a proper rhythm; and they have to be good drivers that follow traffic laws. Another example of a digital game that inserts players in a simulated virtual 
world is The Sims, which allows players to create avatars mirrored in their own lives, where they work, study, and have a personal life and aspirations.

\section{Vocabulary Acquisition}

Vocabulary acquisition once was considered a neglected aspect of language learning; however, "over the last three and a half decades, research in vocabulary acquisition has flourished" (SOK, 2014, p. 21). Several authors have stated that learning vocabulary in a foreign language is, in fact, an important initial step towards the language learning (BEHBAHANI, 2013; NATION, 2001; 2003; SCHMITT, 2000; VAHDAT; YUDINTSEVA, 2015). Vocabulary learning plays a central role since it is usually one of the opening steps towards the building blocks that build whole messages in communication.

According to Laufer (1997), a language speaker can say he/she know a lexical item when they manage the following: their spoken or written forms; words structures - in terms of basic free morpheme, common derivations and inflections; syntactic patterns of a word in a phrase or sentence; their referential, affective and pragmatic meanings; their lexical relations in terms of synonymy, antonymy, and hyponymy; and finally, their common collocations. In consonance, Min (2013) suggested that there are three conditions for speakers or language learners to be able to say they know a word: which words it is usually associated with; what are its grammatical characteristics and how it is pronounced and spelled.

Besides, according to Nation (1990; 2001) and Yudintseva (2015), by the age of 20 years old, an English native speaker knows around 20.000 word families (which consists of the headword, its inflected forms, and closely related derived forms). Also, Nation (2001) stated that the most part of the words an adult knows by the age of 20 is high-frequency words, that is, function or content words related to their daily personal experiences. For instance, 'fieldrelated words' are easier to learn because they are high-frequency, and they represent eighty percent $(80 \%)$ of the vocabulary understanding of an adult person. On the other hand, academic words represent only nine percent (9\%), whereas technical words five percent (5\%), and low frequency words (proper nouns and rare words, for instance) demonstrate also five percent (5\%) (Nation, 2001) of a speaker knowledge.

Having this in mind, however, several authors (CALDERÓN; SLAVIN; SÁNCHEZ, 2011; KELLEY; LESAUX; KIEFFER; FALLER, 2010; OXFORD; CROOKALL, 1990; SHANAHAN; SHANAHAN, 2012) stated that vocabulary instruction would be expected to be at the top of the agenda for language teachers, either for mother or foreign languages. Nevertheless, what has happened in most classrooms throughout many years is usually the opposite: vocabulary, many times and for different reasons - has not been explicitly taught (OXFORD; CROOKALL, 1990). Taking this in consideration, Liu, Lan and Jenkins (2014) identified strategies for vocabulary instruction including and embracing digital resources. In a research investigating lexical learning via an array of technological resources, the authors concluded that there are 12 types 
of appropriate strategies for vocabulary learning, which are: practice, notetaking, keywords, contextualization, grouping, imagery, recombination, deduction, analysis, physical response, translation, and transfer (LIU et. al, 2014).

Similar to techniques for vocabulary development, there are studies (e.g. CHIK, 2014; YUDINTSEVA, 2015) that relate repetition, images association and contextual clues to greater opportunities for learning. Bearing this in mind, it seems relevant to investigate more about how vocabulary can be developed in one's mind and what previous research has mentioned about this topic.

\section{Vocabulary Development: Commitment to Memory}

Foreign language learning, and, therefore, vocabulary learning is, in most cases, a memory task (WILLIAMS; LOVATT, 2003). According to McDermott and Roediger (2018), there are three stages of memory process for learning to take place: encoding, storage and retrieval. While encoding "is defined as the initial learning of information; storage refers to maintaining information over time; retrieval is the ability to access information when you need it" (MCDERMOTT; ROEDIGER, 2018, p. 120).

Encoding is the initial experience of perceiving and learning information that is around people and is selective (where people attend to some information while ignore other) and prolific (where people are constantly encoding events in their lives, trying to understand them) according to McDermott and Roediger (2018). In addition, there seems to be an agreement in the area that claims that some events or information become distinct and are more easily remembered than others. For instance, vivid memories linked with emotional contents may be more easily recalled than those that are not. Many times, also, recalling information may not be accurate as people would imagine: "details do not leap perfectly from the world into a person's mind" (MCDERMOTT; ROEDIGER, 2018, p. 122).

The second stage of memory process is storage, that is the ability to store information in the brain. In accordance with McDermott and Roediger (2018), after having encoded experiences within the nervous system, the brain changes itself to store information that left memory traces through a process of consolidation. This means that memory is a construction of what you actually remember from an event and what you believe it happened: remembering is a reconstruction of the past with the aids of memory traces in storage, and not a perfect reproduction of it (MCDERMOTT; ROEDIGER, 2018).

Finally, the key and third stage of memory process is retrieval. As previously stated, people encode and store lots of information and events daily, creating memory traces in the brain. Accessing these memories is retrieval. However, most of these memories will never be used being brought back to mind consciously because people access only a tiny portion of 
what they lived (MCDERMOTT; ROEDIGER, 2018). Moreover, each time an event is retrieved, it is altered since "memory is constantly changing" (MCDERMOTT; ROEDIGER, 2018, p. 129).

Thus, to improve language learning and memory, events needs to be encoded in conjunction with memory traces that will bring back stored information - that is, remembered events. Other than that, "to maximize retrieval, we should construct meaningful cues that remind us of the original experience, and those cues should be distinctive" (MCDERMOTT; ROEDIGER, 2018, p. 131).

\section{The Sims}

The digital game The Sims is a digital simulation game that allows players to create a virtual family of characters (called Sims), which can be guided by players through the challenges of everyday living (RANALLI, 2008). The game version - The Sims FreePlay - used for the purposes of this study has been downloaded freely and the game was played in participants' tablets and/or smartphones (without payment requirements). With the intention of fulfilling tasks and accomplishing and passing levels, players needed to attend to their Sims' physical and emotional needs, to help them find jobs and resolve domestic and interpersonal problems, and to fill their homes with furniture and appliances. Although the game characters in the game do not speak English, they interact via gesture and an own (nonsense/inaudible) language called Simlish. Nonetheless, the game exposes players to a great deal of written language in English, in the instructions, control and status bar labels, warnings and information updates (RANALLI, 2008).

In this digital game, the player has the objective of creating and maintaining a city with its citizens, private and public buildings, houses, parks and stores. After having selected and bought (with game money) the building place for a house, it is necessary to create the Sim character of the game and house resident.

To create the Sims (characters), the player can choose among several physical characteristics, such as hair color and style, eye color and skin tone, characters' clothes and accessories, and finally, their names and gender. Afterwards, the player must buy or build a house and rebuild it according to the player's preferences. After having the characters' house, the player continues with the missions in the game: to build working places so the characters can work; to build parks and recreational places so characters can have fun and socialize; to build schools so the characters can study; to build stores where characters can buy food, clothes and decoration artifacts; among other actions. Each of these actions happens in the forms of missions, so players get enough score to level up while getting acquainted and familiarized with the game. The higher the level, the more the options to be bought and to be used. For example, in level 3, there are only few stove options ( 1 or 2 ) to be bought for the kitchen renovation, where in level 8 , there are more (4 or 5). The same happens with decoration options: in level 1, there are few kinds of lamp that can be bought, and in level 6 
there are a bigger number of lamp colors and styles to be chosen by the player. The figures ${ }^{3}$ below illustrate some of the game actions and missions.

Figure 1. The Sims introduction

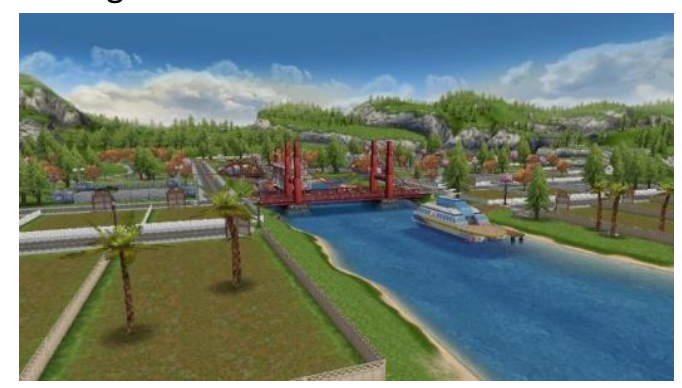

Figure 2. Housing the city

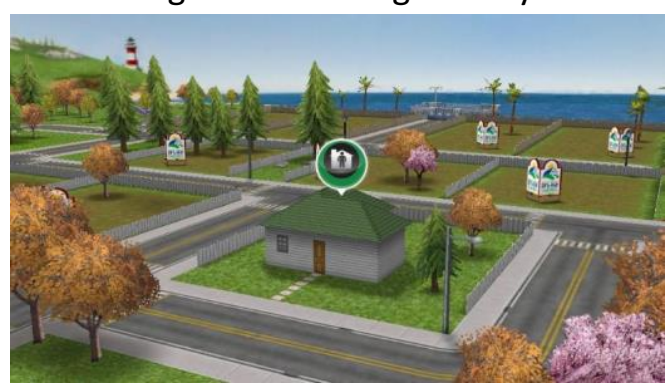

Figure 1 illustrates the opening scene after players downloaded the game The Sims. Figure 2, on the other hand, show the empty city where players are going to be able to build houses, schools, business buildings, and others.

Figure 3. A task being completed

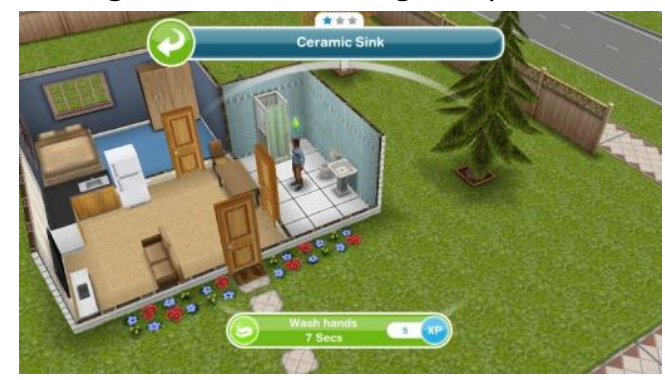

Figure 4. Another task being completed

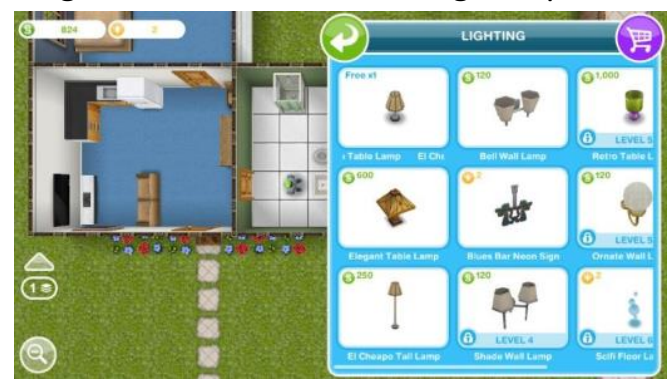

Figure 3 shows one of the first tasks that players must complete: to ask their characters, Sims, to wash their hands. Other personal hygiene tasks are presented similarly, such as going to the bathroom and taking a shower. Figure 4 illustrates building and decorating options, such as buying lamps.

After establishing a house and some basic hygiene habits for their characters, players are allowed to personalize their Sims (characters) in accordance with their own choices. They can choose from hair styles and colors, head shapes and the use of hats, eye color and accessories, and clothing items. Figure 5 exemplifies that.

\footnotetext{
${ }^{3}$ All figures were taken by the author when playing the game The Sims in a smartphone and are part of a personal repertoire. All figures were taken for data collection support in 2016 . Since the game is constantly updated, scenario, graphic quality and wording may have suffered alterations since that time.
} 
Figure 5. Creating the character

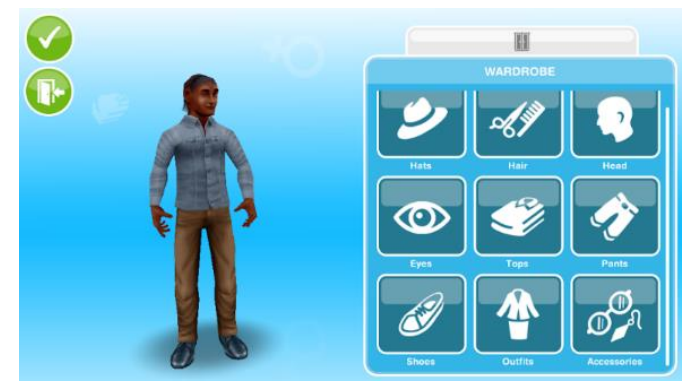

Figure 6. Choosing a job

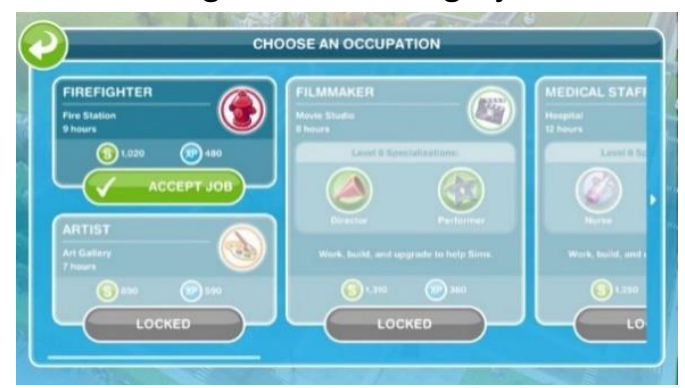

Figures 6 show that as for next tasks, the player must worry about getting a job where the characters will receive money from to buy, for instance, food for their Sims. As the levels get higher, new options are available for the players: there are new buildings and decor options, new different designed houses, new outfits and stylish looks available, which usually keep players motivated to keep playing in order to reach those levels with those new choices to make and brand-new artifacts to buy.

Furthermore, The Sims is an example of a digital game especially used for vocabulary learning, since it provides gamers with vocabulary of actions carried out daily, such as cooking, cleaning, building, eating and shopping. This game was selected as an object for this investigation due to these reasons: a) its age limit enforcement compatible with participants age (players can be under eighteen to play); b) its availability, being that it can be easily found and downloaded online for free with small smartphone memory capacity; c) its resemblance to real life daily situations and vocabulary; and d) its popularity among teenagers' players ${ }^{4}$. Words from the game were selected for the pre-test, post-test and post-delayed test regarding their high frequency use in the first game tasks and game tutorial in order of appearance.

\section{Methodology}

The research ${ }^{5}$ design consists of a qualitative quasi-experimental investigation. Data collection involved 8 gaming sessions, including procedures such as pre-test, post-test and post-delayed test, as well as narrative inquiries that explored participants perceptions regarding their vocabulary acquisition through digital gameplaying The Sims.

The present article, therefore, consists of an investigation of vocabulary acquisition in English as a foreign language with the assistance of the digital game The Sims. This research

\footnotetext{
${ }^{4}$ Teenagers under 18 years old represent $28 \%$ of digital games players. Among all players, $42 \%$ play with friends as a way to bond and to have fun altogether. In addition, digital games such as The Sims, which received an $\mathrm{E}$ (Everyone) rating, are the majority among players, with $34 \%$ of downloads (ESA, 2018).

${ }^{5}$ This article is a result of a doctoral research.
} 
involved a sample of 19 beginner English learners enrolled at high school integrated courses at the Federal Institute of Santa Catarina (IFSC). The participants were students of the third semester of the Integrated High School of the Technical Courses of Chemistry, Sanitation, Building, Electrical, and Electronics of IFSC, campus Florianópolis, Santa Catarina. Their age ranged from 15 to 18 years old. They came previously from public or private where they first started learning English as Foreign Language since their sixth year of Elementary School years.

At IFSC, participants studied technical courses integrated to high school. Therefore, besides regular high school subjects, such as History, Geography, Portuguese, English, Mathematics, among others, the participants of the present study were enrolled in technical subjects of their specific areas, such as Civil Construction, Safety and Hygiene at Work, Biochemistry, Statistics, Business Management and Machinery and Equipment, etc. Moreover, for them, learning English was not focused on the learning of grammar per se, or on English for Specific Purposes (ESP), but on the language structure for formal and informal communication settings and academic purposes, especially because students are driven to improve their rhetoric skills and to participate in exchange programs (where they may use English).

All participants of this research were beginner learners of English, whose proficiency had been established through the results of a placement test ${ }^{6}$ in English in the beginning of their third semester ${ }^{7}$ - where the learning of English begins in the integrated technical courses.

Data collection was divided in two phases: the first phase of data collection consisted of pre-test, post-test, delayed post-test, to measure the participants' scores as the result of the game playing session. The second phase of data collection consisted of a written narrative where participants could gather and reflect on their perceptions based on the game playing sessions (and on their general opinion regarding digital games playing) in relation to their vocabulary development in English.

\footnotetext{
${ }^{6}$ The placement test applied by the English teachers of IFSC campus Florianópolis consist of two steps: 1) an online reading and writing placement test that grades students according to the Common European Framework of Reference for Languages (CEFRL); and 2) an oral interview with the intent to listen and to grade students' oral performance of English. Both tests were applied in the beginning of the semester in order to place students according to their knowledge of English. According to the CEFRL, students / participants of this investigation were considered A1 or A2, or Basic Users of English. Individual results of each participant in the placement test were provided from IFSC professionals in order to ensure that the students' levels of proficiency were similar and were, in fact, consistent with their beginner level.

${ }^{7}$ The third semester at IFSC campus Florianópolis is equivalent to the second year of a regular Brazilian high school system, and students have English classes for 3 semesters in total.
} 


\section{Data Analysis}

In this section, I present and discuss scores of 3 participants, Juliana, Marcelo and Willian ${ }^{8}$. Analysis is divided by participants so their data can be analyzed taking into consideration their individual differences, experiences and scores.

\section{Juliana}

Juliana's scores showed that this participant already had some previous knowledge on the lexical items presented in the game The Sims. This conclusion can be made taking into consideration her scores in the pre-test, in which she got 19 correct answers (out of 25). This number, in fact, remained increasing to 22 in the post-test and remained stable in the delayed post-test. On one hand, Juliana's scores are high regarding correct answers in the tests; on the other hand, her scores shifted from zero to 3 considering both blank answers and incorrect answers. Juliana's scores in the number of correct answers, therefore, might be considered having a beneficial impact and increase on her learning development.

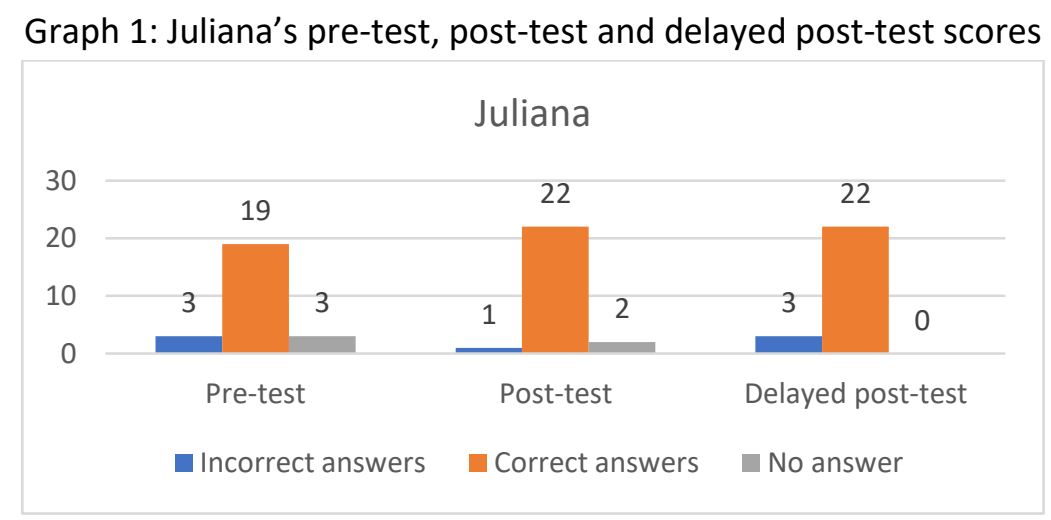

Displayed in graph 1, her scores got higher between the pre-test and post-test, and then remained the same. This may indicate that lexical items might have been stored in her memory, guiding Juliana's learning processes during gameplaying sessions.

\section{Marcelo}

Marcelo's scores, as showed in graph 2, reveal complementary results: the number of correct answers and answers left in blank have grown in opposite directions. The more

\footnotetext{
${ }^{8}$ Due to space constraints, I had to select only three participants' data to be analyzed in this article. For data analysis of all participants in this investigation, please read the complete dissertation.
} 
Marcelo answered correctly, the less he left blank the activities proposed in the tests. Thus, the number of incorrect answers has remained fairly the same throughout the tests, in a number of 2, going from one to another among the same words in his tests.

As depicted in graph 2, Marcelo's highest scores were answered in the post-test, taken right after the 8 gaming sessions. In the post-test, this participant answered 22 activities correctly, 2 were left in blank, and one was answered incorrectly. The scores in the delayed post-test, although it diminished reasonably (in comparison to the post-test scores), can still be considered as an ascending result in terms of lexical items acquired. In the delayed posttest, Marcelo answered 16 activities correctly, 6 remained left in blank, and 3 were answered incorrectly.

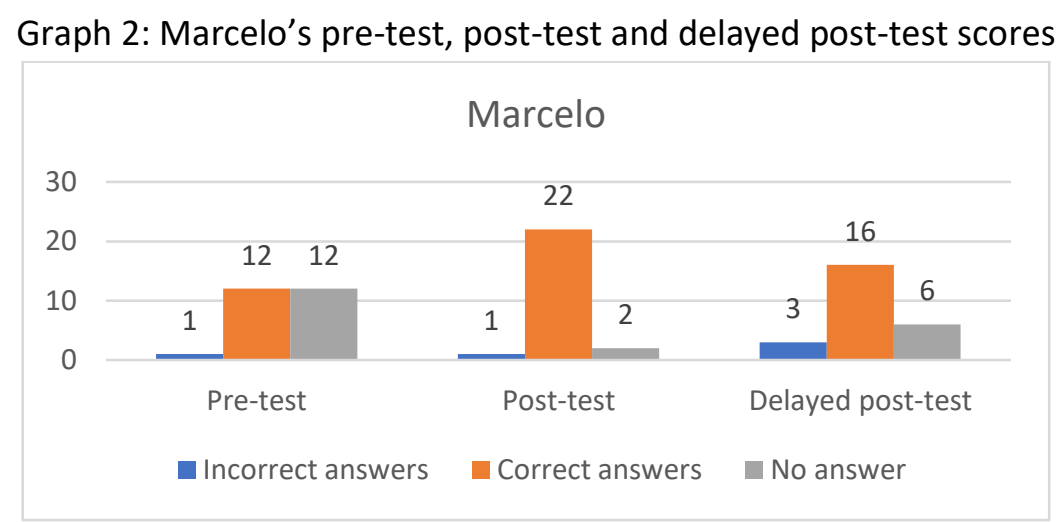

In the delayed post-test, a slight decrease in the number of correct answers was already expected, especially because the gaming sessions have already ended and the participant had not access anymore to the words from the game. Altogether, the results indicated that Marcelo may have learned lexical items in English by playing The Sims.

\section{Willian}

While Willian managed to keep his scores of correct answers one of the highest for this research, he also managed to keep low the scores for answers that had been incorrect and left in blank. This shows that that he might have learned while gameplaying The Sims. In the pre-test, Willian answered properly 19 activities, and this states that he had already previous knowledge of the game environment and lexical items. Besides that, the number of incorrect answers dropped by half if we take the pre-test and the delayed post-test into comparison, going from 4 to 2 in the final test. Even with some small variation in the post-test, the left in blank answers have remained the same in the first and last test applied to participants. 
Graph 3: Willian's pre-test, post-test and delayed post-test scores

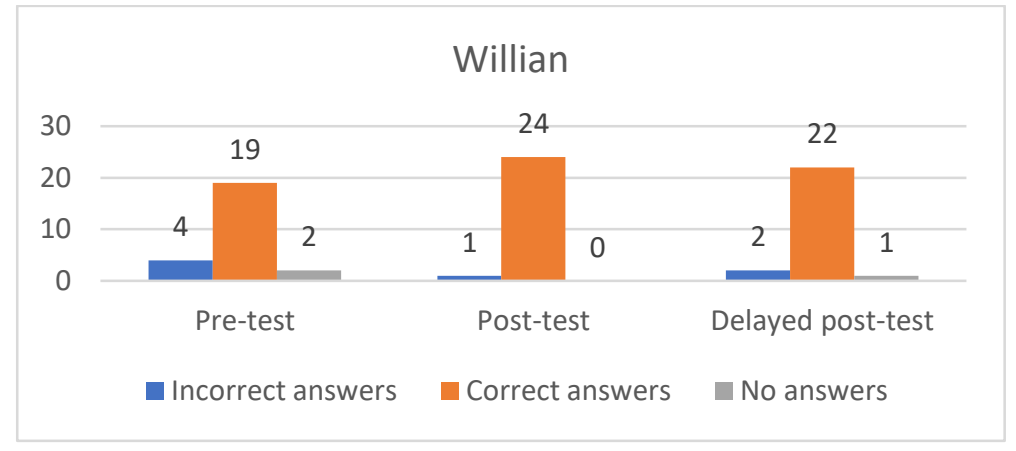

It seems plausible to state that Willian has retained lexical items in English throughout gaming sessions, although he had already previous knowledge concerning most of them. This can be seen in graph 3 above. Furthermore, playing The Sims in an EFL classroom environment can be truly beneficial, especially if the associations among the images and the written tasks displayed in the game are explored.

In general, the pre-test scores indicated that participants' knowledge of English and their proficiency levels were different - these scores served as a basis for data analysis in matters of indication and illustration of participants individual learning processes that may (or not) have happened throughout the gaming sessions of The Sims. Considering the post-test, there was an increase in the number of correct answers. This increase can be interpreted as a positive and beneficial sign of learning lexical items through the use of the digital games The Sims as part of classroom activities. The post-test was administered right after the end of the 8 gaming sessions and it showed that the number of correct answers increased in the same way that the number of incorrect or blank answers decreased. General results for delayed post-test data indicated that some participants learned lexical items more than others. This can be explained through the high number of repetitions and encounter with words allowed by the game, and also through participants' motivational states (since The Sims allowed different choices in the game that led players to access different levels of lexical items repetition in the game, this could also have played a role).

Now we move to the narrative inquiries excerpts analysis. All excerpts here presented have been translated (from Portuguese) to English.

Daniel

According to his written narrative inquiry, Daniel stated that he had never played The Sims previously. Through the game display that inserted characters in context allowing association among images and text, Daniel stated that he learned especially some verbs and jobs, as he exemplifies: 
I already knew the game, but I had never played it, I did not find it cool and I started to play. [...] I learned lots of verbs and several jobs. In the beginning I found it a little bit difficult, and it was, since my English is poor, but it was improving thanks to the images and actions that the characters performed, which were really good. I reached the conclusion that in spite of not knowing English it is possible to play digital games and learn with them ${ }^{9}$.

In general, Daniel attributed his good results to the game characteristics of allowing image and actions / images association, being repetitive and allowing frequency of lexical items to take place in context. In fact, as previous research (Nation, 2014; Laufer, 2017) shows, repeated and frequent exposure enhance learning opportunities.

Helena

In her narrative writing, Helena mentioned that she had learned some new words while playing The Sims in English, even though they are considered a small number by the participant.

I started to play The Sims in the classes of English [...] In the beginning I didn't like it so much, but then over the time I was adapting myself to the game and to the instructions in English. I learned some new words, such as bathroom and firefighter. This learning method called my attention because I could connect learning and a present device to most people nowadays: the cellphone ${ }^{10}$.

In her narrative text, Helena mentioned that her interest and adaptation to the game increased during gameplaying The Sims. The more she played, the more she felt motivated. Besides, although she mentioned she had learned just a few words throughout the gaming sessions, she managed to give examples in her text, which can be considered a positive aspect

\footnotetext{
${ }^{9}$ Já conhecia o jogo, mas nunca tinha jogado, não achava muito legal comecei a jogar. [...] Aprendi muitos verbos e várias profissões. No começo eu achei um pouco difícil, e foi, já que meu inglês é muito fraco, mas foi melhorando graças às imagens e às ações que os bonecos faziam, que eram muito boas. Cheguei à conclusão que mesmo não sabendo inglês é possível jogar jogos e aprender com eles.

${ }^{10}$ Eu comecei a jogar The Sims nas aulas de inglês, no qual a professora nos propôs participar de uma pesquisa do seu doutorado. No começo não gostava tanto, mas como eu passar do tempo fui me adaptando ao jogo e as suas instruções em inglês. Aprendi poucas palavras novas, entre elas estão bathroom e firefighter. Esse método de aprendizagem me chamou bastante atenção, pois consegui conectar o ensino e um objeto tão presente para a maioria das pessoas hoje em dia: o celular.
} 
of her learning process, since producing or reproducing lexical items is one of the final stages of learning new words (HATCH; BROWN, 1995). Helena mentioned that she enjoyed linking the learning of English to the use of cellphone in the classroom environment, since, as she claimed, is so ubiquitous nowadays.

Besides motivation stated in Helena's narrative text, in the classroom, while playing The Sims, I observed that Helena felt really motivated and concentrated in the game environment, smiling while playing. Helena was a motivated participant - and she described and exemplified lexical items she learned due to playing The Sims, and how this was a fruitful experience for her.

Raquel

In her narrative text, Raquel mentioned that she did not know for sure to state or assess her learning outcomes with gameplaying The Sims. However, Raquel mentioned that her interest in the game increased throughout the gaming sessions.

In the beginning when the teacher talked about the game I thought it would be boring. I had already heard of it, and the idea to stay in the classroom playing The Sims in English (I really hated English) was not a thing that pleased me. However, I don't know if it is because I started to like the game, [...] I became addicted to keep playing it. I confess that I don't know how to assess if I learned more with the game, but I liked it a lot ${ }^{11}$.

During the gaming sessions, Raquel had been one of the participants that had shown more interest to play the game and to comment on her choices with her colleagues and friends, whenever possible. According to Derakhshan and Khatir (2015), digital games are advantageous and effective in learning vocabulary largely because they are motivating. Through my observations of Raquel in class during gaming sessions, it seems possible to state that this participant learned English mostly guided by her motivation to play the game The Sims.

In general, participants' narrative excerpts indicated that their knowledge of English progressed or developed with the aid of playing The Sims. Many participants could still

\footnotetext{
${ }^{11}$ No começo quando a professora falou do jogo eu achei que seria chato, já sabia da existência dele, e a ideia de ficar na sala jogando The Sims em inglês (eu realmente detestava inglês) não era uma coisa que me agradava. Porém não sei porque comecei a gostar dele (talvez tenha sido por causa da professora incrível que estava dando a aula), e mais, fiquei viciada, sempre que tinha internet começava a jogar. Confesso que não sei avaliar se com o jogo aprendi mais, mas eu gostei tanto que tenho até agora The Sims no meu celular, e ainda jogo.
} 
remember some words they had learned in the game even months later, mainly because of repetition frequency or due to their association with their personal lives. There were some positive aspects mentioned by participants, such as the game display that allowed associations between words and actions or images and motivation elicited by the The Sims.

In general, participants could observe positive aspects elicited from the game. They mentioned the game have helped them learning new words because they could relate to those routine experiences, that is, they were really close to their own daily life. In addition, the association among the written text and images and actions in the game helped players to understand the meaning of lexical items in context. Also, the repetition of those actions, images and written text were mentioned by most participants as a game characteristic that was beneficial for their learning of lexical words. Besides, all these characteristics triggered motivation and emotional states, allowing players to be immersed and enjoy the use of The Sims for learning and developing vocabulary items in the classes of English at IFSC.

\section{Concluding Remarks}

With an outgrowing number of studies in the area, digital games are being investigated in their use for learning purposes. Moreover, entertainment digital games played for learning purposes during class time, such as The Sims in this investigation context, allow different outcomes and impacts: knowledge and content understanding; perceptual and cognitive skills, motor skills, behavior change, soft and social skills, affective and motivational outcomes, and physiological outcomes (CONNOLLY; BOYLE; MACARTHUR; HAINEY; 2012), such as positive emotions.

Numerous benefits and characteristics from gameplaying the digital game The Sims have been mentioned throughout this article. Some benefits mentioned by participants are: a) the motivational aspect of playing a digital game during classroom time for learning vocabulary in English as a foreign language; $b$ ) the opportunities to associate images to text or to game actions, that, in turn, created learning opportunities, since it allowed better understanding and better memorization; c) the integration of digital technologies in the classroom; d) participants prospects to explore their agency skills; e) the resemblance to real life actions and with real life vocabulary, since The Sims allowed them to experience in a virtual environment; and f) repetition, frequency and number of encounters with words.

This investigation recognized that The Sims may have had a transformational impact on vocabulary development in English in that particular context. The Sims and other several entertainment digital games are known to provide motivational activities, maturing as a medium technology for EFL learning. Benefits of digital game playing combined to EFL learning contexts are acknowledged by many scholars (CONNOLLY ET. AL, 2012; GEE, 2009; SQUIRE, 2006; SYKES, 2013; YUNDITSEVA, 2015), although there is much more that can be investigated in the area, especially because digital technologies are updated constantly. What remains, 
therefore, is that there are surely profits from these designed experiences. It seems safe to state that digital games such as The Sims have a potential for being used in a teaching and learning EFL perspective: it is not an issue if they should be used in learning settings, because they should, but for whom, what purposes and in what contexts (SQUIRE, 2006).

\section{References}

AGHLARA, L.; TAMJID, N. H. The effect of digital games on Iranian children's vocabulary retention in foreign language acquisition. Procedia - Social and Behavioral Sciences, v. 29, p. 552-560, 2011. https://doi.org/10.1016/j.sbspro.2011.11.275

CALDERÓN, M.; SLAVIN, R.; SÁNCHEZ, M. Effective Instruction for English Learners. The Future of Children, v. 21, n. 1, 2011. https://doi.org/10.1353/foc.2011.0007

CHIK, A. Learner autonomy development through digital gameplay. Journal of Digital Culture \& Education, v. 3, n. 1, p. 30-45. 2011.

CHIK, A. Digital Gaming and Language Learning: Autonomy and Community. Language Learning \& Technology, v. 18, n. 2, p. 85-100. 2014.

CONNOLLY, T. M.; BOYLE, E. A.; MACARTHUR, E.; HAINEY, T.; BOYLE, J. M. A systematic literature review of empirical evidence on computer games and serious games. Computers \& Education, v. 59, p. 661-686. 2012. https://doi.org/10.1016/i.compedu.2012.03.004

DEMPSEY, J. V.; LUCASSEN B.A.; HAYNES L.L.; CASEY M.S. Instructional applications of computer games. Annual Meeting of the American Educational Research Association (AERA). 1996.

DERAKHSHAN, A.; KHATIR, E. D. The Effects of Using Games on English Vocabulary Learning. Journal of Applied Linguistics and Language Research, v. 2, n. 2, p. 39-47. 2015.

GEE, J. P. Learning by Design: good video games as learning machines. E-Learning and Digital Media, v. 2, n. 1, p. 5-16. 2005. https://doi.org/10.2304/elea.2005.2.1.5

GEE, J. P. Deep learning properties of good digital games: How far can they go? In Serious Games: Mechanisms and Effects. Routledge Taylor \& Francis Group. 2009. p. 67-82.

GEE, J. P.; HAYES, E. R. Women and Gaming: The Sims and 21st Century Learning. Palgrave Macmillan. 2010. https://doi.org/10.1057/9780230106734

GRAMIGNA, M. R. Jogos de Empresa. Pearson Education: São Paulo. 2007.

HATCH, E.; BROWN, C. Vocabulary, Semantics, and Language Education. Cambridge: Press Syndicate of the University of Cambridge. 1995.

JAVERLÄ, S.; EKMAN, I.; KIVIKANGAS, J. M.; RAVAJA, N. Digital Games as an Experiment Stimulus. Transactions of the Digital Games Research Association (DIGRA), v. 1, n. 2, 2014. https://doi.org/10.26503/todigra.v1i2.16

KELLEY, J. G.; LESAUX, N. K.; KIEFFER, M. J.; FALLER, S. E. Effective Academic Vocabulary Instruction in the Urban Middle School. The Reading Teacher, v. 64, n. 1, p. 5-14. 2010. https://doi.org/10.1598/RT.64.1.1 
LAUFER, B. What's in a word that makes it hard or easy: some intralexical factors that affect the learning of words. In: Vocabulary: Description, Acquisition and Pedagogy. Schmitt, N. and McCarty, M. (eds.). p. 140 - 155. 1997.

LAUFER, B. From word parts to full texts: Searching for effective methods of vocabulary learning. Language Teaching Research, v. 21, n. 1, p. 5-11. 2017. https://doi.org/10.1177/1362168816683118

LIU, S. H. J.; LAN, Y; JENKINS, J. R. Technology-Enhanced Strategy Use for Second Language Vocabulary Acquisition. English Teaching \& Learning, v. 38, n. 2, p. 105-130. 2014.

MCDERMOTT, K. B.; ROEDIGER, H.L. Memory (Encoding, Storage, Retrieval). P. 117-153. In: Butler, A. (Ed.) General Psychology FA2018. Noba Project: Milwaukie, OR. 2018.

MIN, Y. Vocabulary Acquisition: Practical Strategies for ESL Students. Journal of International Students, v. 3, n. 1, p. 64- 69. 2013.

MORAN, J. A integração das tecnologias na educação, 2013. Disponível em: http://www.eca.usp.br/prof/moran/site/textos/tecnologias eduacacao/integracao. pdf. Acesso em: 26 jun. 2015.

NATION, I. S. P. The Goal of Vocabulary Learning. Teaching and learning vocabulary. New York: Newbury House, 1st Ed. 1990. p. 6-22. https://doi.org/10.1017/CBO9781139524759.003

NATION, I. S. P. Learning Vocabulary in Another Language. Cambridge University Press. 2001. https://doi.org/10.1017/CBO9781139524759

NATION, I.S.P. Vocabulary research into practice. Language Teaching, v. 44, n. 4, p. 529-539. 2011. https://doi.org/10.1017/S0261444811000267

OXFORD, R.; CROOKALL, D. Vocabulary Learning: A Critical Analysis of Techniques. TESL Canada Journal, v. 7, n. 2, p. 9-30. 1990. https://doi.org/10.18806/tesl.v7i2.566

PRENSKY, M. Digital Game-Based Learning. New York: Paragon House. 2007.

RAMOS, D. K.; LORENSET, C. C.; PETRI, G. Jogos Educacionais: Contribuições da Neurociência à Aprendizagem. Revista X, v. 2, p. 1-17, 2016. https://doi.org/10.5380/rvx.v2i1.2016.46530

RANALLI, J. Learning English with The Sims: exploiting authentic computer simulation games for L2 learning. Computer Assisted Language Learning, v. 21, n. 5, p. 441-455. 2008. https://doi.org/10.1080/09588220802447859

SAFFARIAN, R.; GORJIAN, B. Effect of computer-based video games for vocabulary acquisition among young children: An experimental study. Journal of Comparative Literature and Culture (JCLC), v. 1, n. 3, p. 44-48. 2012.

SAHRIR, M. S.; YUSRI G. A. R. (2012). Online Vocabulary Games for Teaching and Learning Arabic. GEMA Online ${ }^{\circledR}$ Journal of Language Studies, v. 12, n. 3, p. 961-977, 2012.

SAVI, R.; ULBRICHT, V. R. Jogos Digitais Educacionais: benefícios e desafios. Novas Tecnologias na Educação - CINTED-UFRGS, v. 6, n. 2. 2008. https://doi.org/10.22456/1679-1916.14405

SCHMITT, N. Vocabulary in Language Teaching. Cambridge University Press, Cambridge.

SHANAHAN, T.; SHANAHAN, C. What Is Disciplinary Literacy and Why Does It Matter? Top Lang Disorders, v. 32, n. 1, p. 7-18, 2000. https://doi.org/10.1097/TLD.0b013e318244557a 
SOK, S. Deconstructing the Concept of 'Incidental' L2 Vocabulary Learning. Working papers in TESOL \& Applied Linguistics, v. 14, n. 2, p. 21-37, 2014.

S $\varnothing$ RENSEN, B. H.; MEYER, B. Serious games in language learning and teaching: A theoretical perspective. Proceedings of the 2007 Digital Games Research Association, p. 559-566. Retrieved from http://www.digra.org/dl/db/07312.23426.pdf. 2007.

SQUIRE, K. From Content to Context: Videogames as Designed Experience. Educational Researcher, v. 35, n. 8, p. 19-29, 2006. https://doi.org/10.3102/0013189X035008019

SYKES, J. M. - "Just" Playing Games? A Look at the Use of Digital Games for Language Learning. The Language Educator. October Special Issue on Technology, p. 32-35, 2013.

SYKES, J. M.; REINHARDT, J. Language at play: digital games in second and foreign language teaching and learning. Boston, MA: Pearson. 2013.

TUMOLO, C. H. S. Recursos digitais e aprendizagem de inglês como língua estrangeira. Revista Ilha do Desterro, n. 66, p. 203-238, 2014. https://doi.org/10.5007/2175-8026.2014n66p203

VAHDAT, S.; BEHBAHANI, A. R. The Effect of Video Games on Iranian EFL Learners' Vocabulary Learning. Reading Matrix: An International Online Journal, v. 13, n. 1, p. 61-71. 2013.

WANGNHEIM, C. G.; WANGENHEIM, A. Ensinando Computação com Jogos. Florianópolis / SC: Bookes Editora, 2012.

WILLIAMS, J. N.; LOVATT, P. Phonological Memory and Rule Learning. Language Learning, v. 53, n. 1, p. 67-121. 2003. https://doi.org/10.1111/1467-9922.00211

YUDINTSEVA, A. Game-Enhanced Second Language Vocabulary Acquisition Strategies: A Systematic Review. Open Journal of Social Sciences 2015; v. 03, p. 101-109. 2015. https://doi.org/10.4236/iss.2015.310015

Recebido em: 07/07/2019

Aceito em: 19/11/2019 